\title{
PEMENUHAN HAK KONSTITUSIONAL WARGA NEGARA INDONESIA : STUDI KASUS JAMINAN KESEHATAN NASIONAL
}

\author{
Ulul Adzemi Romansyah, Ahmad Labib, Muridah Isnawati \\ Fakultas Hukum Universitas Muhammadiyah Surabaya
}

\begin{abstract}
Health is an important factor for every citizen and thus require collateral for its survival. The objective is to determine the normative regulation and its efforts to investigate the implementation and proper normative adjustment pattern to give recognition, security, and protection of the constitutional rights of Indonesian citizens accordance with the mandate of Article $28 \mathrm{H}$ paragraph (1), paragraph (2), paragraph ( 3) and Article 34 paragraph (1) and (2) 1945. The method used is normative juridical statute approach. The results obtained are finding normative regulations governing the national health insurance in the national social security system implemented social security administering bodies associated with membership and health services that are not appropriate if adjusted against the constitutional rights of Indonesian citizens. The remedies that can be taken in the event of problems regarding the implementation of the program is not health insurance through the judicial institution namely the National Human Rights Commission and the Ombudsman as well as through the courts at the district court level to the Supreme Court and the Constitutional Court.
\end{abstract}

Keywords: citizens, health insurance, constitutional rights, remedies.

\section{A. Pendahuluan}

Kesehatan merupakan faktor utama bagi setiap manusia untuk menjaga keberlangsungan kehidupan didunia, kesehatan sangat besar manfaatnya bagi setiap orang, kegiatan yang meliputi faktor situasional dapat tercapai dengan baik apabila didalam prosesnya kesehatan dapat terus terjaga.

Faktor situasional adalah mencakup faktor lingkungan dimana manusia berada atau bertempat tinggal, baik lingkungan fisik, sosial, budaya, ekonomi, politik, dan sebagainya". ${ }^{1}$

Sebaliknya, apabila didalam proses kegiatan faktor situasional seseorang tidak mampu menjaga kesehatannya, maka yang terjadi tujuan dalam proses kegiatan tersebut akan tertunda bahkan akan mengalami kegagalan, "kesehatan merupakan isu krusial yang harus dihadapi setiap negara karena berkorelasi langsung dengan pengembangan integritas pribadi

1 Soekidjo Notoatmodjo, 2010, Ilmu perilaku kesehatan,PT. Rineka Cipta, Jakarta. Hlm. 17. 
setiap individu supaya dapat hidup bermartabat". ${ }^{2}$

Berkaitan dengan kepentingan bangsa bahwa kesehatan merupakan bagian dari tujuan pembangunan nasional, dasar - dasar ini diperoleh dari amanah Undang - Undang Dasar Negara Republik Indonesia Tahun 1945, (selanjutnya disebut UUD NRI 1945), yang dimaksudkan didalam Pasal 28H UUD NRI 1945.

Disebutkan bahwa penyelenggara upaya kesehatan diatur oleh pemerintah, sehingga perlu adanya jaminan terhadap kesehatan masyarakat, hal itu dilaksanakan pemerintah dengan melaksanakan Sistem Jaminan Kesehatan Nasional (SJSN), pemerintah didalam melaksanakan jaminan kesehatan membentuk aturan yang berbentuk Peraturan Presiden Republik Indonesia nomor 12 tahun 2013 tentang Jaminan Kesehatan, ${ }^{3}$ (selanjutnya disebut Perpres 12/2013 kemudian dilakukan perubahan melalui Peraturan Presiden Republik Indonesia nomor 111 tahun 2013 tentang Perubahan atas Peraturan Presiden nomor 12 tahun 2013 tentang Jaminan

\footnotetext{
${ }^{2}$ Titon Slamet Kurnia, 2007, Hak atas derajat kesehatan optimal sebagai HAM di Indonesia, PT. Alumni, Bandung. Hlm. 2.

${ }^{3}$ Lembaran Negara Republik Indonesia Tahun 2013 Nomor 29
}

Kesehatan, yang selanjutnya disebut Perpres 111/2013). ${ }^{4}$

Keberadaan Perpres 12/2013 dan Perpres 111/2013 ini mempertimbangkan keberadaan Undang-Undang Republik Indonesia Nomor 40 Tahun 2004 tentang Sistem Jaminan Sosial Nasional, ${ }^{5}$ (selanjutnya disebut UU 40/2014 dan Undang-Undang Republik Indonesia Nomor 24 Tahun 2011 tentang Badan Penyelenggaraan Jaminan Sosial, ${ }^{6}$ yang selanjutnya disebut UU 24/2011).

\section{B. Rumusan masalah}

1. Apakah terdapat pengaturan normatif tentang pengakuan, jaminan, dan perlindungan terhadap hak konstitusional Warga Negara Indonesia dibidang Jaminan Kesehatan Nasional $(\mathrm{JKN})$.

2. Apakah tata cara pelaksanaan tentang pengakuan, jaminan, dan perlindungan terhadap hak konstitusional Warga Negara Indonesia dibidang JKN telah sesuai dengan pengaturan normatif yang ada.

\footnotetext{
${ }^{4}$ Lembaran Negara Republik Indonesia Tahun 2013 Nomor 255

5 Lembaran Negara Republik Indonesia Tahun 2004 Nomor 150; Tambahan Lembaran Negara Republik Indonesia Nomor 4456

6 Lembaran Negara Republik Indonesia Tahun 2011 Nomor 116; Tambahan Lembaran Negara Republik Indonesia Nomor 5256
} 


\section{Metode Penelitian}

Metode yang digunakan adalah hukum normatif dengan pendekatan perundang undangan (statute approach)

\section{Pembahasan}

Pengaturan Normatif Tentang Pengakuan, Jaminan, dan Perlindungan Terhadap Hak Konstitusional Warga Negara Indonesia Dibidang Jaminan Kesehatan Nasional

Dasar untuk mewujudkan penyelenggaraan JKN secara kostitusional dijamin didalam UUD NRI 1945, Konvensi ILO nomor 102/1952 juga menyatakan tentang penyelenggaraan jaminan sosial yang didalamnya termasuk kepentingan kesehatan ditambah dikeluarkannya International Convenant on Economic, Social, and Cultural Rights dan International Convenant on Civil and Political Rights atas persetujuan Majelis Umum PBB. ${ }^{7}$ Penyelenggaraan JKN merupakan bagian dari pelaksanaan Jaminan Sosial bagi masyarakat sehingga pemerintah untuk melaksanakan amanah UUD 1945 membentuk payung hukum berupa UU 40/2004 dan UU 24/2011,

${ }^{7}$ Ahmad Nizar Shihab, 2012, Hadirnya negara di tengah rakyatnya pasca lahirnya undang - undang nomor 24 tahun 2011 tentang Badan Penyelenggara Jaminan Sosial, Jurnal Legislasi Indonesia Vol. 9 No. 2, ISSN 0216-1338, Jakarta. Hlm. 181.

${ }^{8}$ Rudy Hendra Pakpahan, Eka N. A. M. Sihombing, Op. Cit, hal. 169. adapun yang menjadi pertimbangan pemerintah didalam membentuk kedua undang - undang tersebut sebagai berikut :

Pertimbangan dalam pembuatan UU 40/2004 :

Setiap orang berhak atas jaminan sosial untuk dapat memenuhi kebutuhan dasar hidup yang layak dan meningkatkan martabatnya menuju terwujudnya masyarakat Indonesia yang sejahtera, adil dan makmur dan untuk memberikan jaminan sosial yang menyeluruh, negara mengembangkan Sistem Jaminan Sosial Nasional bagi seluruh rakyat Indonesia.

Pertimbangan dalam pembuatan UU 24/2011 :

Sistem jaminan sosial nasional merupakan program negara yang bertujuan memberikan kepastian perlindungan dan kesejahteraan sosial bagi seluruh rakyat, Untuk mewujudkan tujuan sistem jaminan sosial nasional perlu dibentuk badan penyelenggara yang berbentuk badan hukum berdasarkan prinsip kegotongroyongan, nirlaba, keterbukaan, kehati - hatian, akuntabilitas, portabilitas, kepesertaan bersifat wajib, dana amanat dan hasil pengelolaan dana jaminan sosial seluruhnya untuk pengembangan program dan untuk sebesar - besar kepentingan 
peserta sehingga perlu dibentuk Badan Penyelenggara Jaminan Sosial dengan undang - undang yang merupakan transformasi empat Badan Usaha Milik Negara (PT. Jamsostek, PT. Askes, PT. Taspen, PT. Asabri) untuk mempercepat terselenggaranya sistem jaminan sosial nasional bagi seluruh rakyat Indonesia.

Pemerintah perlu membuat aturan yang lebih khusus mengenai jaminan kesehatan dalam bentuk peraturan presiden untuk memberikan perlindungan hukum dalam pelaksanaan program JKN. ${ }^{9}$ Peraturan yang dimaksud untuk memberikan perlindungan hukum lebih khusus berupa Perpres 12/2013 yang disebutkan dalam pertimbangannya bahwa dalam rangka melaksanakan ketentuan Pasal 13 ayat (2), Pasal 21 ayat (4), Pasal 22 ayat (3), Pasal 23 ayat (5), Pasal 26, Pasal 27 ayat (5), dan Pasal 28 ayat (2) UU 40/2004 dan ketentuan Pasal 15 ayat (3) dan Pasal 19 ayat (5) huruf a UU 24/2011, sehingga perlu menetapkan Peraturan Presiden Tentang Jaminan Kesehatan. Kemudian seiring berjalan setelah ditetapkannya Perpres 12/2013 pemerintah menganggap perlu adanya beberapa perubahan didalam pasal - pasal pada peraturan presiden tersebut, sehingga

\footnotetext{
${ }^{9}$ Ahmad Nizar Shihab. Op.cit, hal 187.
}

berdasarkan pertimbangan tersebut ditetapkan Perpres 111/2013.

Terdapat beberapa bentuk aturan yang menjadi payung hukum dalam pelaksanaan program JKN yang terdiri dari beberapa aturan yang tingkatannya dalam teknik peraturan perundang - undangan telah dikenal adanya hierarki perundang undangan, ${ }^{10}$ antara lain sebagai berikut :

a. Undang - undang

1) UU No. 40 Tahun 2004 tentang Sistem Jaminan Sosial Nasional

2) UU No. 24 Tahun 2011 tentang Badan Penyelenggara Jaminan Sosial

b. Peraturan Pemerintah

1) PP No. 101 Tahun 2012 tentang Penerima Bantuan Iuran Jaminan Kesehatan

2) PP No. 85 Tahun 2013 tentang tata cara hubungan antar Lembaga Badan Penyelenggara Jaminan Sosial

3) PP No. 86 Tahun 2013 Tentang tata cara pengenaan sanksi administratif kepada pemberi kerja selain penyelenggara negara dan setiap orang, selain pemberi kerja, pekerja, dan penerima bantuan iuran dalam penyelenggaraan jaminan sosial

\footnotetext{
${ }^{10}$ M. Dimyati Hartono, 2009, Problematik dan solusi amandemen Undang - Undang Dasar 1945, PT Gramedia Pustaka Utama, Jakarta. Hlm. 69.
} 
4) PP No. 87 Tahun 2013 Tentang pengelolaan aset jaminan sosial kesehatan

5) PP No. 88 Tahun 2013 Tentang tata cara pengenaan sanksi administratif bagi anggota dewan pengawas dan anggota direksi Badan Penyelenggara Jaminan Sosial

6) PP No. 89 Tahun 2013 Tentang pencabutan Peraturan Pemerintah nomor 69 tahun 1991 tentang pemeliharaan kesehatan bagi pegawai negeri sipil, penerima pensiun, veteran, perintis kemerdekaan beserta keluarganya

7) PP No. 90 Tahun 2013 Tentang pencabutan Peraturan Pemerintah nomor 28 tahun 2003 tentang subsidi dan iuran Pemerintah dalam penyelenggaraan asuransi kesehatan bagi pegawai negeri sipil dan penerima pension.

c. Peraturan Presiden

1) Peraturan Presiden No. 44 Tahun 2008 tentang Susunan Organisasi dan Tata Kerja Tata Cara Pengangkatan Penggantian dan Pemberhentian Anggota Dewan Jaminan Sosial Nasional

2) Peraturan Presiden No. 12 Tahun 2013 tentang Jaminan Kesehatan
3) Peraturan Presiden No. 107 Tahun 2013 tentang Pelayanan Kesehatan Tertentu Berkaitan dengan Kegiatan Operasional Kementerian Pertahanan, Tentara Nasional Indonesi, dan Kepolisian Negara Republik Indonesia

4) Peraturan Presiden No. 108 Tahun 2013 tentang Bentuk dan Isi Laporan Pengelolaan Program Jaminan Sosial 5) Peraturan Presiden No. 109 Tahun 2013 tentang Penahapan Kepesertaan Program Jaminan Sosial

6) Peraturan Presiden No. 110 Tahun 2013 tentang Gaji atau Upah dan Manfaat Tambahan Lainnya Serta Insentif Bagi Anggota Dewan Pengawas dan Anggota Direksi Badan Penyelenggara Jaminan Sosial

7) Peraturan Presiden No. 111 Tahun 2013 tentang Perubahan Atas Peraturan Presiden No. 12 Tahun 2013 tentang Jaminan Kesehatan. ${ }^{11}$

Selain aturan berdasarkan hierarki peraturan perundang - undangan tersebut masih terdapat beberapa aturan pelaksana yang meliputi Peraturan Menteri Kesehatan, Keputusan Menteri Kesehatan, Surat Edaran Menteri Kesehatan, dan

${ }^{11}$ http://www.jkn.kemkes.go.id/unduhan.p hp? page $=3$, diakses tanggal 30 November 2016 . 
bentuk surat edaran lainnya berkenaan dengan sosialisasi program JKN.

a. Hak pemerintah

Memperoleh dana operasional untuk penyelenggaraan program yang bersumber dari Dana Jaminan Sosial dan/atau sumber lainnya sesuai dengan ketentuan peraturan perundang-undangan dan memperoleh hasil monitoring dan evaluasi penyelenggaraan program Jaminan Sosial dari DJSN setiap 6 (enam) bulan.

b. Kewajiban pemerintah

1. Memberikan nomor identitas tunggal kepada Peserta.

2. Mengembangkan aset Dana Jaminan Sosial dan aset BPJS untuk sebesarbesarnya kepentingan Peserta.

3. Memberikan informasi melalui media massa cetak dan elektronik mengenai kinerja, kondisi keuangan, serta kekayaan dan hasil pengembangannya.

4. Memberikan Manfaat kepada seluruh Peserta sesuai dengan UndangUndang tentang Sistem Jaminan Sosial Nasional.

5. Memberikan informasi kepada Peserta mengenai hak dan kewajiban untuk mengikuti ketentuan yang berlaku.
6. Memberikan informasi kepada Peserta mengenai prosedur untuk mendapatkan hak dan memenuhi kewajibannya.

7. Memberikan informasi kepada Peserta mengenai saldo jaminan hari tua dan pengembangannya 1 (satu) kali dalam 1 (satu) tahun

8. Memberikan informasi kepada Peserta mengenai besar hak pensiun 1 (satu) kali dalam 1 (satu) tahun.

9. Membentuk cadangan teknis sesuai dengan standar praktik aktuaria yang lazim dan berlaku umum.

10. Melakukan pembukuan sesuai dengan standar akuntansi yang berlaku dalam penyelenggaraan Jaminan Sosial.

11. Melaporkan pelaksanaan setiap program, termasuk kondisi keuangan, secara berkala 6 (enam) bulan sekali kepada Presiden dengan tembusan kepada DJSN.

a. Hak masyarakat

1. Memperoleh identitas peserta.

2. Memperoleh manfaat pelayanan kesehatan pada fasilitas kesehatan yang bekerjasama dengan BPJS Kesehatan.

3. Memperoleh manfaat dan informasi tentang hak dan kewajiban serta 
prosedur pelayanan kesehatan sesuai dengan ketentuan yang berlaku.

4. Menyampaikan keluhan atau pengaduan, kritik dan saran secara lisan atau tertulis ke kantor BPJS Kesehatan.

b. Kewajiban masyarakat

1. Membayar iuran sesuai ketentuan yang berlaku.

2. Melaporkan data kepesertaan kepada BPJS kesehatan dengan menunjukkan identitas peserta pada saat pindah domisili dan atau pindah kerja.

3. Menjaga kartu peserta agar tidak rusak, hilang atau dimanfaatkan oleh orang yang tidak berhak.

4. Mentaati semua ketentuan dan tata cara pelayanan kesehatan.

Pelaksanaan Pengaturan Normatif Tentang Pengakuan, Jaminan, dan Perlindungan Terhadap Hak Konstitusional Warga Negara Indonesia Dibidang Jaminan Kesehatan Nasional

Kepesertaan didalam BPJS Kesehatan dibagi menjadi 2 kelompok golongan yaitu peserta Penerima Bantuan Iuran (PBI) dan peserta bukan Penerima Bantuan Iuran.
Kriteria peserta PBI sesuai PP No. 101 tahun 2012 tentang penerima bantuan iuran jaminan kesehatan sebagai berikut :

1. Peserta PBI Jaminan Kesehatan meliputi orang yang tergolong fakir miskin dan orang tidak mampu.

2. Kriteria Fakir Miskin dan orang tidak mampu ditetapkan oleh menteri di bidang sosial setelah berkoordinasi dengan menteri dan /atau pimpinan lembaga terkait.

3. Kriteria Fakir Miskin dan Orang tidak mampu sebagaimana dimaksud menjadi dasar bagi lembaga yang menyelenggarakan urusan pemerintahan di bidang statistik untuk melakukan pendataan.

4. Data Fakir Miskin dan Orang Tidak Mampu yang telah diverifikasi dan divalidasi sebagaimana dimaksud, sebelum ditetapkan sebagai data terpadu oleh Menteri di bidang sosial, dikoordinasikan terlebih dahulu dengan menteri yang menyelenggarakan urusan pemerintahan di bidang keuangan dan menteri dan/atau pimpinan lembaga terkait.

5. Data terpadu yang ditetapkan oleh Menteri dirinci menurut provinsi dan kabupaten/kota.

6. Data terpadu sebagaimana dimaksud menjadi dasar bagi penentuan jumlah 
nasional PBI Jaminan Kesehatan. Data terpadu sebagaimana dimaksud, disampaikan oleh Menteri di bidang sosial kepada menteri yang menyelenggarakan urusan pemerintahan di bidang kesehatan dan DJSN.

7. Menteri yang menyelenggarakan urusan pemerintahan di bidang kesehatan mendaftarkan jumlah nasional PBI Jaminan Kesehatan yang telah ditetapkan sebagaimana dimaksud sebagai peserta program Jaminan Kesehatan kepada BPJS Kesehatan.

8. Penetapan jumlah PBI Jaminan Kesehatan pada tahun 2014 dilakukan dengan menggunakan hasil Pendataaan Program Perlindungan Sosial tahun 2011.

Apabila kemudian hari terdapat perubahan data terhadap golongan PBI yang tidak sesuai dengan kriteria yang telah disebutkan, maka perlu dilakukan adanya penetapan ketentuan sebagai berikut :

1. Penghapusan data fakir miskin dan orang tidak mampu yang tercantum sebagai PBI Jaminan Kesehatan karena tidak lagi memenuhi keriteria.

2. Penambahan data Fakir Miskin dan Orang Tidak Mampu untuk dicantumkan sebagai PBI Jaminan
Kesehatan karena memenuhi kriteria Fakir Miskin dan Orang Tidak Mampu.

3. Perubahan data PBI Jaminan Kesehatan sebagaimana dimaksud diverifikasi dan divalidasi oleh Menteri di bidang sosial.

4. Perubahan data ditetapkan oleh Menteri di bidang sosial setelah berkoordinasi dengan Menteri yang menyelenggaraka$\mathrm{n}$ urusan pemerintahan di bidang keuangan dan Menteri dan/atau pimpinan lembaga terkait.

5. Verifikasi dan validasi terhadap perubahan data PBI Jaminan Kesehatan sebagaimana dimaksud dilakukan setiap 6 (enam) bulan dalam tahun anggaran berjalan.

6. Penduduk yang sudah tidak menjadi Fakir Miskin dan sudah mampu, wajib menjadi peserta Jaminan Kesehatan dengan membayar Iuran.

Berdasarkan ketentuan didalam Perpres 12/2013 dan aturan perubahannya Perpres 111/2013 Peserta bukan Penerima Bantuan Iuran (Non-PBI) Jaminan Kesehatan merupakan peserta yang tidak tergolong fakir miskin dan orang tidak mampu yang terdiri dari pekerja penerima upah dan anggota keluarganya, pekerja bukan penerima upah dan anggota keluarganya serta bukan pekerja dan anggota keluarganya. Peserta Non - PBI dapat mengikutsertakan anggota keluarga 
lainnya selain yang telah disebutkan, kepesertaaan jaminan kesehatan bersifat wajib dan dilakukan secara bertahap sehingga mencakup seluruh penduduk. ${ }^{12}$

a. Iuran bagi Peserta PBI

Iuran Jaminan Kesehatan bagi peserta PBI Jaminan Kesehatan dibayar oleh Pemerintah melalui Anggaran Pendapatan Belanja Negara (APBN), sedangkan bagi penduduk yang didaftarkan oleh Pemerintah Daerah dibayar oleh Pemerintah Daerah.

b. Iuran bagi Peserta Non - PBI

Iuran bagi peserta Non - PBI sebagai berikut :

1. Iuran Jaminan Kesehatan bagi Peserta Pekerja Penerima Upah yang terdiri atas Pegawai Negeri Sipil, Anggota TNI, Anggota Polri, Pejabat Negara, dan Pegawai Pemerintah Non Pegawai Negeri sebesar 5\% (lima persen) dari Gaji atau Upah per bulan dengan ketentuan $3 \%$ (tiga persen) dibayar oleh pemberi kerja dan $2 \%$ dibayar oleh peserta, pemberi kerja yang dimaksud dalam kategori peserta ini dalam kewajiban pembayaran iuran adalah Pemerintah Pusat dan Pemerintah Daerah. Pemerintah untuk

\footnotetext{
${ }^{12}$ Mundiharno, 2012, Peta jalan menuju universal coverage jaminan kesehatan, Jurnal Legislasi Indonesia Vol. 9 No. 2, ISSN 0216-1338, Jakarta. Hlm. 208.
}

Iuran Jaminan Kesehatan bagi Pegawai Negeri Sipil Pusat, Anggota TNI, Anggota Polri, Pejabat Negara, dan Pegawai Pemerintah Non Pegawai Negeri Pusat sedangkan Pemerintah Daerah untuk Iuran Jaminan Kesehatan bagi Pegawai Negeri Sipil Daerah dan Pegawai Pemerintah Non Pegawai Negeri Daerah.

2. Iuran Jaminan Kesehatan bagi Peserta Pekerja Penerima Upah selain Peserta dibawah Instansi Pemerintah mulai diberlakukan pembayaran mulai tanggal 1 Januari 2014 sampai dengan 30 Juni 2015 sebesar 4,5\% (empat koma lima persen) dari Gaji atau Upah per bulan dengan ketentuan 4\% (empat persen) dibayar oleh Pemberi Kerja dan 0,5\% (nol koma lima persen) dibayar oleh Peserta, kemudian mulai tanggal 1 Juli 2015 iuran dikenakan sebesar 5\% (lima persen) dari Gaji atau Upah per bulan dengan ketentuan 4\% (empat persen) dibayar oleh Pemberi Kerja dan 1\% (satu persen) dibayar oleh Peserta.

Berdasarkan Perpres 111/2013 setiap pemberi kerja wajib mendaftarkan dirinya dan pekerjanya sebagai peserta jaminan kesehatan kepada BPJS Kesehatan dengan membayar iuran. ${ }^{13}$

\footnotetext{
${ }^{13}$ Ibid. Hlm. 218.
} 
Dalam hal pemberi kerja tidak mendaftarkan pekerjanya kepada BPJS Kesehatan pekerja pada tempat pemberi kerja tersebut berhak mendaftarkan dirinya sebagai peserta jaminan kesehatan dengan iuran sebagaimana yang telah diatur berdasar ketentuan tentang iuran terhadap golongan pekerja, peserta pekerja penerima upah wajib menyampaikan perubahan data kepesertaan kepada pemberi kerja dan pemberi kerja wajib melaporkan perubahan data kepesertaan kepada BPJS Kesehatan. Sedangkan bagi setiap orang yang bukan pekerja diwajibkan pula mendaftarkan dirinya dan keluarganya sebagai peserta dengan membayar iuran secara mandiri, untuk ruang perawatan kelas III sebesar Rp.25.000,- per orang per bulan, ruang perawatan kelas II sebesar Rp.42.500,- per orang per bulan, dan ruang perawatan kelas I Rp.59.500 per orang per bulan.

Terhadap pelayanan kesehatan telah diatur mengenai ruang lingkup pelayanan yang diberikan bagi peserta jaminan kesehatan sebagaimana diatur dalam Perpres 12/2013 dan aturan perubahannya Perpres 111/2013 serta Peraturan BPJS Kesehatan No. 1 Tahun 2014 dengan ketentuan pelayanan sebagai berikut :
1. Pelayanan kesehatan tingkat pertama antara lain administrasi pelayanan, pelayanan promotif dan preventif, pemeriksaan dan pengobatan serta konsultasi medis, Tindakan medis non spesialistik operatif maupun non operatif, pelayanan obat dan bahan medis habis pakai, transfusi darah sesuai dengan kebutuhan medis, pemeriksaan penunjang diagnostik laboratorium tingkat pratama, rawat Inap tingkat pertama sesuai dengan indikasi medis.

2. Pelayanan kesehatan rujukan tingkat lanjutan antara lain administrasi pelayanan, pemeriksaan dan pengobatan serta konsultasi spesialistik oleh dokter spesialis dan subspesialis, tindakan medis spesialistik baik bedah maupun non bedah sesuai dengan indikasi medis, pelayanan obat dan bahan medis habis pakai, pelayanan penunjang diagnostik lanjutan sesuai dengan indikasi medis, rehabilitasi medis, pelayanan darah, pelayanan kedokteran forensik klinik, pelayanan jenazah pada pasien yang meninggal setelah dirawat inap di fasilitas kesehatan yang bekerjasama dengan bpjs kesehatan berupa pemulasaran jenazah tidak termasuk peti mati dan mobil jenazah, perawatan inap non 
intensif dan perawatan inap di ruang intensif

3. Persalinan yang ditanggung BPJS Kesehatan di fasilitas kesehatan tingkat pertama maupun tingkat lanjutan adalah persalinan sampai dengan anak ketiga tanpa melihat anak hidup atau meninggal. Berdasarkan Surat Edaran Menkes RI No. 32/2014 terhadap bayi yang baru lahir dari peserta PBI secara otomatis dijamin oleh BPJS Kesehatan dengan mencatat dan dilaporkan kepada BPJS Kesehatan oleh fasilitas kesehatan untuk kepentingan rekonsiliasi data PBI, bagi peserta Non - PBI untuk golongan pekerja penerima upah terhadap anak ke -1 (satu) sampai dengan anak ke-3 (tiga) dari peserta pekerja penerima upah secara otomatis dijamin oleh BPJS Kesehatan, sedangkan anak ke-4 (empat) atau lebih dari peserta penerima upah dijamin hingga hari ke-7 (tujuh) sejak kelahirannya dan harus segera didaftarkan sebagai peserta. Bagi peserta pekerja bukan penerima upah dan peserta bukan pekerja dijamin hingga hari ke-7 (tujuh) sejak kelahirannya dan harus segera didaftarkan sebagai peserta, sebagaimana seperti anak ke-4 (empat) atau lebih dari peserta penerima upah, apabila bayi hingga hari ke-7 (tujuh) sejak kelahirannya tidak didaftarkan bayi tersebut tidak dijamin oleh BPJS Kesehatan.

4. Ambulan, hanya diberikan untuk pasien rujukan dari fasilitas kesehatan satu ke fasilitas kesehatan lainnya, dengan tujuan menyelamatkan nyawa pasien. Pelayanan Ambulan merupakan pelayanan transportasi pasien rujukan dengan kondisi tertentu antar Fasilitas Kesehatan disertai dengan upaya atau kegiatan menjaga kestabilan kondisi pasien untuk kepentingan keselamatan pasien. Pelayanan Ambulan hanya dijamin bila rujukan dilakukan pada Fasilitas Kesehatan yang bekerjasama dengan BPJS atau pada kasus gawat darurat dari Fasilitas Kesehatan yang tidak bekerja sama dengan BPJS Kesehatan dengan tujuan penyelamatan nyawa pasien.

Terhadap pelayanan kesehatan yang dapat dijamin oleh BPJS Kesehatan terdapat jenis pelayanan kesehatan yang tidak dijamin sebagaiman diatur didalam Perpres 111/2013 meliputi hal- hal sebagai berikut :

1. Pelayanan kesehatan yang dilakukan tanpa melalui prosedur sebagaimana diatur dalam peraturan yang berlaku 
2. Pelayanan kesehatan yang dilakukan di fasilitas kesehatan yang tidak bekerjasama dengan BPJS Kesehatan, kecuali dalam keadaan darurat

3. Pelayanan kesehatan yang telah dijamin oleh program jaminan kecelakaan kerja terhadap penyakit atau cedera akibat kecelakaan kerja atau hubungan kerja sampai nilai yang ditanggung oleh program jaminan kecelakaan kerja

4. Pelayanan kesehatan yang telah dijamin oleh program jaminan kecelakaan lalu lintas yang bersifat wajib sampai nilai yang ditanggung oleh program jaminan kecelakaan lalu lintas

5. Pelayanan kesehatan yang dilakukan di luar negeri

6. Pelayanan kesehatan untuk tujuan estetik

7. Pelayanan untuk mengatasi infertilitas

8. Pelayanan meratakan gigi (ortodonsi)

9. Gangguan kesehatan/penyakit akibat ketergantungan obat dan/ atau alcohol

10. Gangguan kesehatan akibat sengaja menyakiti diri sendiri, atau akibat melakukan hobi yang membahayakan diri sendiri

11. Pengobatan komplementer, alternatif dan tradisional, termasuk akupuntur, shin she, chiropractic, yang belum dinyatakan efektif berdasarkan penilaian teknologi kesehatan (health technology assessment)

12. Pengobatan dan tindakan medis yang dikategorikan sebagai percobaan (eksperimen)

13. Alat kontrasepsi, kosmetik, makanan bayi, dan susu

14. Perbekalan kesehatan rumah tangga

15. Pelayanan kesehatan akibat bencana pada masa tanggap darurat, kejadian luar biasa/wabah.

16. Biaya pelayanan kesehatan pada kejadian tak diharapkan yang dapat dicegah

17. Biaya pelayanan lainnya yang tidak ada hubungan dengan manfaat jaminan kesehatan yang diberikan klaim perorangan.

Bagi peserta BPJS diberikan pelayanan skrining kesehatan yang diberikan secara perorangan dan selektif yang bertujuan untuk mendeteksi resiko penyakit serta mencegah dampak lanjutan dari resiko penyakit tertentu, penyakit tersbut meliputi antara lain diabetes mellitus tipe 2, hipertensi, kanker leher rahim, kanker payudara dan penyakit lain yang ditetapkan oleh Menteri.

Pelayanan skrining kesehatan dimulai dengan analisis riwayat kesehatan yang dilakukan sekurang-kurangnya 1 (satu) tahun sekali, apabila perserta 
teridentifikasi mempunyai resiko riwayat kesehatan tersebut harus dilakukan penegakan diagnosa melalui pemeriksaan penunjang diagnostik tertentu kemudian diberikan pengobatan sesuai dengan indikasi medis.

Apabila di suatu daerah belum tersedia fasilitas kesehatan yang memenuhi, syarat guna memenuhi kebutuhan medis sejumlah peserta terhadap BPJS Kesehatan wajib memberikan kompensasi untuk memperkecil beban biaya yang dikeluarkan peserta, ${ }^{14}$ penentuan daerah belum tersedia fasilitas kesehatan yang memenuhi syarat guna memenuhi kebutuhan medis sejumlah peserta ditetapkan oleh Dinas Kesehatan setempat atas pertimbangan BPJS Kesehatan dan Asosiasi Fasilitas Kesehatan, kompensasi dapat diberikan berupa penggantian uang tunai, pengiriman tenaga kesehatan dan penyediaan fasilitas kesehatan tertentu.

a. Permasalahan kepesertaan

Dalam hal kepesertaan BPJS Kesehatan ditemukan adanya beberapa bentuk permasalahan terkait aturan yang telah ditetapkan antara lain sebagai berikut:

1. perintah bagi masyarakat yang tergolong bukan penerima upah dan

\footnotetext{
${ }^{14}$ Mundiharno. Op.cit, hal. 209.
}

bukan pekerja untuk secara wajib mendaftarkan diri sebagai peserta beserta seluruh anggota keluarganya pada BPJS Kesehatan dengan beban iuran per orang per bulan sesuai Pasal 16F Perpres 111/2013, perihal penetapan iuran Jaminan Kesehatan pada BPJS Kesehatan yang mewajibkan pembayaran iuran per orang per bulan hal tersebut bertentangan dengan pemberian manfaat jaminan kesehatan bagi anggota keluarga dari peserta didalam Pasal 20 UU 40/2004 serta Pasal 3 dan Pasal 13d UU 24/2011.

2. Adanya penetapan pemberlakuan penggunaan kartu peserta BPJS Kesehatan yang telah terdaftar dan membayar iuran pertama baru dapat dilakukan setelah 7 hari pendaftaran, sehingga selama 7 hari tersebut masyarakat tidak dapat menikmati pelayanan kesehatan melalui BPJS Kesehatan sebagaimana disebutkan didalam Pasal 10 Peraturan BPJS 4/2014 tentang tata cara pendaftaran dan pembayaran peserta perorangan Badan Penyelenggara Jaminan Sosial Kesehatan, hal tersebut bertentangan dengan makna jaminan kesehatan pada Pasal 1 Perpres 12/2013 kemudian bertentangan dengan Pasal 3 UU 24/2011 mengenai tujuan BPJS dan 
Pasal 19 ayat (2) UU 40/2004 mengenai tujuan penyelenggaraan jaminan kesehatan.

b. Permasalahan pelayanan kesehatan

Dalam hal pelayanan BPJS Kesehatan terdapat beberapa bentuk permasalahan terkait aturan yang telah ditetapkan anatara lain sebagai berikut :

1. Sistem pembagian kelas pelayanan kesehatan non medis berdasarkan besaran nilai iuran yang dibayarkan peserta BPJS Kesehatan serta pemberian fasilitas kesehatan terendah bagi peserta penerima bantuan iuran BPJS Kesehatan sesuai Pasal 23 Pepres 111/2013 tentulah tidak sesuai dengan konstitusi karena tidak adanya persamaan hak bagi warga negara.

2. Terhadap perbedaan kelas pelayanan tersebut masih ditambah dengan adanya ketentuan administrasi klinik pelayanan kesehatan yang tidak memberikan kemudahan bagi masyarakat untuk menikmati pelayanan kesehatan sebagaimana telah terdaftar sebagai peserta BPJS Kesehatan seperti penetapan klinik kesehatan yang ditentukan 1 (satu) klinik per peserta, adanya mekanisme rujukan yang menyulitkan masyarakat untuk mendapatkan segera pelayanan kesehatan sebagaimana Pasal 29 Perpres 12/2013.

Kepesertaan BPJS diatur dalam Pasal 14 sampai dengan Pasal 19 UU 24/2011 serta pada Pasal 2 sampai dengan Pasal 19 Perpres 12/2013 dan Perpres 111/2013 yang mengatur tentang pendaftaran kepesertaan, permasalahan kepesertaan, status kepesertaan dan pembayaran iuran.

Pelayanan kesehatan diatur dalam Pasal 12 dan Pasal 13 UU 24/2011 serta pada Pasal 20 sampai dengan Pasal 45 Perpres 12/2013 dan Perpres 111/2013 yang menerangkan atas hak dan kewajiban BPJS Kesehatan selaku penyelenggara yang terdiri tentang manfaat jaminan kesehatan, koordinasi manfaat, penyelenggaraan pelayanan kesehatan ditinjau dari prosedur pelayanan kesehatan, pelayanan obat dan bahan medis, pelayan gawat darurat, pelayanan dimana tidak adanya fasilitas kesehatan yang memenuhi syarat, serta penjaminan atas tanggung jawab tersedianya pelayanan kesehatan yang memadai.

Keorganisasian BPJS Kesehatan sebagai pelaksana penyelenggara kesehatan diatur dalam Pasal 20 sampai dengan Pasal 47 UU 24/2011 yang mengatur tentang organ BPJS, persyaratan tata cara pemilihan dan penetapan serta 
pemberhentian anggota dewan pengawas dan anggota direksi, pertanggung jawaban penyelenggaraan program BPJS, kegiatan pengawasan dalam penyelengaraan program BPJS, pengelolahan aset, dan tentang ketentuan pembubaran BPJS.

Negara Indonesia adalah negara yang berdasarkan atas hukum sebagaimana disebutkan dalam konstitusi Pasal 1 ayat (3) UUD $1945,{ }^{15}$ segala sesuatu hubungan antara hak dan kewajiban yang melekat pada warga negara didalam kehidupan berbangsa dan bernegara terbentuk berdasarkan atas tatanan hukum yang ada, membahas tentang JKN negara memberikan ruang bagi warga negara berkedudukan yang sama didepan hukum untuk melakukan tindakan hukum menyelesaikan segala permasalahan kehidupan berbangsa dan bernegara melalui lembaga hukum terdiri dari lembaga bukan peradilan dan lembaga peradilan.

Bentuk upaya penyelesaian hukum yang dapat dilakukan dalam permasalahan jaminan kesehatan adalah penyelesaian melalui lembaga bukan peradilan dalam hal ini dapat melalui Komisi Nasional Hak Asasi Manusia atau Komnas HAM dan Komisi Ombudsman Nasional.

\footnotetext{
${ }^{15}$ Andi Mappetahang Fatwa, 2009, Potret konstitusi pasca amandemen UUD 1945, Penerbit buku Kompas, Jakarta. Hlm. 47.
}

Komnas HAM memiliki kewenangan dalam rangka menangani perkara pengaduan atas pelanggaran HAM berdasarkan UU No. 39 tahun 1999 dengan tujuan mengembangkan kondisi yang kondusif bagi pelaksanaan HAM sesuai dengan Pancasila, Undang - undang Dasar 1945 dan Piagam PBB serta Deklarasi Hak Asasi Manusia dan tujuan selanjutnya meningkatkan perlindungan dan penegakan HAM guna berkembangnya pribadi manusia Indonesia seutuhnya dan kemampuannya berpartisipasi dalam berbagai bidang kehidupan dengan melaksanakan fungsi pengkajian, penelitian, penyuluhan, pemantauan dan mediasi tentang HAM. Sementara pelanggaran hak atas terjadinya maladministrasi yang berkenaan dengan aspek - aspek pelayanan publik berupa tindakan yang tidak sesuai norma diterapkan kepada masyarakat oleh perlengkapan negara dalam hal ini BPJS Kesehatan. ${ }^{16}$

Selain lembaga bukan peradilan terdapat lembaga yang penting untuk memutus perkara tentang permasalahan dalam JKN yaitu melalui lembaga peradilan, lembaga peradilan merupakan instrument penting yang menjamin tegaknya HAM dalam hal ini jaminan

\footnotetext{
${ }^{16}$ Titon Slamet Kurnia. Op.cit. Hlm.305.
} 
kesehatan dengan putusan yang bersifat mengikat dan eksekutabel, ${ }^{17}$ lembaga peradilan ini terdiri dari tingkatan pengadilan pada tingkat pengadilan negeri hingga Mahkamah Agung dan Mahkamah Konstitusi.

Adapun beberapa penyesuaian materiil didalam peraturan terkait jaminan kesehatan nasional dalam UU 40/2004 dan UU 24/2011 beserta peraturan turunannya yang berupa peraturan pelaksana agar berdasarkan konstitusi tentang hal - hal sebagai berikut :

1 Dalam hal kepesertaan BPJS Kesehatan ditemukan adanya perintah bagi masyarakat golongan bukan penerima upah dan bukan pekerja untuk secara wajib mendaftarkan diri sebagai peserta dan seluruh anggota keluarganya dengan perhitungan iuran dibayar per orang per bulan, seharusnya anggota keluarga dari peserta tidaklah membayar iuran tersendiri melainkan mendapatkan manfaat jaminan kesehatan dari pendaftaran yang telah dilakukan kepala keluarga atau yang telah mendaftarkan diri sebagai peserta dalam keluarga tersebut bukan melakukan iuran tersendiri oleh masing - masing orang dalam anggota keluarga tersebut.

\footnotetext{
${ }^{17}$ Ibid. Hlm.287.
}

2 Adanya penetapan pemberlakuan penggunaan kartu peserta BPJS Kesehatan yang telah terdaftar baru dapat dilakukan setelah 7 (tujuh) hari pendaftaran, seharusnya tidak dibenarkan adanya aturan seperti itu apabila terkait tentang kepentingan masyarakat dalam menikmati manfaat jaminan kesehatan, hal tersebut merupakan bentuk ketidakpedulian pemerintah bagi masyarakatnya yang tentunya dalam masa sebelum 7 (tujuh) hari sangat dimungkinkan masyarakat membutuhkan manfaat jaminan kesehatan. Seharusnya aturan seperti ini tidaklah tepat diberlakukan berkaitan dengan upaya negara melakukan jaminan kesehatan bagi warga negaranya tanpa adanya pembatasan didalam hak atas jaminan kesehatan itu sendiri.

3 Sistem pembagian kelas pelayanan kesehatan non medis berdasarkan besaran nilai iuran yang dibayarkan peserta BPJS Kesehatan serta pemberian fasilitas kesehatan terendah bagi peserta penerima bantuan iuran BPJS Kesehatan, hal ini tidak mencerminkan adanya upaya untuk mewujudkan kesetaraan didalam memberikan sebuah jaminan kesehatan secara menyeluruh bagi warga negara, 
seharusnya tidak perlu adanya perbedaan kelas pelayanan terlebih lagi adanya penetapan kelas terendah bagi peserta penerima bantuan iuran.

4 Adanya ketentuan administrasi klinik pelayanan kesehatan yang tidak memberikan kemudahan bagi masyarakat untuk menikmati pelayanan kesehatan sebagaimana telah terdaftar sebagai peserta BPJS Kesehatan seperti penetapan klinik kesehatan yang ditentukan 1 (satu) klinik per peserta, adanya mekanisme rujukan yang menyulitkan masyarakat untuk mendapatkan segera pelayanan kesehatan, seharusnya masyarakat diberikan kemudahan didalam memenuhi haknya sehingga terhadap jaminan kesehatan yang diharapkan terwujud secara benar dan nyata.

Berdasarkan pertimbangan dalam penyesuaian materiil dapat menjadi pertimbangan dilakukan penyesuaian formil terhadap aturan - aturan yang ada antara lain sebagai berikut :

1. Terkait kewajiban pendaftaran peserta golongan bukan pekerja bukan penerima upah dan seluruh anggota keluarganya pada BPJS Kesehatan dengan ketentuan pembayaran iuran per orang perbulan, perlu adanya penyesuaian dan pengkajian ulang terhadap Pasal 16F Perpres 111/2013.

2. Terhadap penetapan pemberlakuan penggunaan kartu peserta BPJS Kesehatan yang telah terdaftar baru dapat digunakan setelah 7 hari pendaftaran perlu adanya penyesuaian dan pengkajian ulah terhadap Pasal 10 Peraturan BPJS 4/2014 tentang tata cara pendaftaran dan pembayaran peserta perorangan Badan Penyelenggara Jaminan Sosial Kesehatan.

3. Sistem pembagian kelas pelayanan kesehatan non medis berdasarkan besaran nilai iuran yang dibayarkan peserta BPJS Kesehatan serta pemberian fasilitas kesehatan terendah bagi peserta penerima bantuan iuran BPJS Kesehatan perlu dilakukan penyesuaian Pasal 23 Perpres 111/2013.

4. Penetapan klinik kesehatan yang ditentukan 1 (satu) klinik per peserta, adanya mekanisme rujukan yang menyulitkan masyarakat untuk mendapatkan segera pelayanan kesehatan perlu adanya penyesuaian sebagaimana Pasal 29 Perpres 12/2013.

\section{Penutup}

Kesimpulan

Berdasarkan dari uraian dan pembahasan dalam bab - bab yang telah dikemukakan sebelumnya, maka dapat 
dibuat kesimpulan bahwa jaminan

Kesehatan Nasional merupakan bagian dari penegakan Hak Asasi Manusia yang dilindungi berdasarkan konstitusi, sehingga atas hak tersebut merupakan bentuk hak konstitusional yang dimiliki Warga Negara Indonesia yang diselenggarakan berdasarkan ketetapan konstitusi sebagaimana dasar atas penyelenggaraannya adalah pada pasal 28 $\mathrm{H}$ ayat (1), ayat (2), ayat (3) serta pasal 34 ayat (1) dan ayat (2) UUD 1945, terdapat aturan pelaksana dibawah UUD 1945 berupa UU 40/2004 dan UU 24/2011 serta peraturan pelaksana lainnya.

Pengaturan dan pelaksanan normatif terkait dengan jaminan kesehatan nasional pada UU 40/2004 dan UU 24/2011 serta peraturan pelaksana dibawahnya perlu adanya penyesuaian didalam Pasal 16 F, Pasal 23 Perpres 111/2013, Pasal 29 Perpres 12/2013 dan Pasal 10 Peraturan BPJS 4/2014 yang dinilai tidak tepat sehingga tidak dapat melaksanakan amanah pasal $28 \mathrm{H}$ ayat (1), ayat (2), ayat (3) serta pasal 34 ayat (1) dan ayat (2) UUD 1945 dalam memberikan pengakuan, jaminan, dan perlindungan terhadap hak konstitusional Warga Negara Indonesia.
Saran

Terhadap pelaksanaa penyelenggar -aan Jaminan Kesehatan Nasional ini terkait pemenuhan hak konstitusional Warga Negara Indonesia terdapat beberapa saran yang dapat disampaikan agar mampu menjadi pertimbangan penyelenggaran jaminan kesehatan yang lebih baik yaitu diperlukannya sosialisasi yang lebih baik oleh pemerintah kepada masyarakat secara luas menyeluruh sehingga seluruh masyarakat dapat mengetahui keberadaan penyelenggaraan $\mathrm{JKN}$, pemerintah harus memberikan kemudahan dan keleluasaan bagi masyarakat untuk menikmati jaminan kesehatan yang ada serta tidak perlu adanya bentuk batasan - batasan atau syarat - syarat yang sifatnya mempersulit dan merugikan masyarakat.

Terkait dengan UU 40/2004 dan UU 24/2011 serta segala bentuk aturan pelaksana yang telah dibuat terhadap sifat yang berkaitan dengan pembatasan hak konstitusional warga negara perlu adanya upaya - upaya hukum untuk memperbaiki aturan tersebut dan perlu dilakukan judisial review agar sesuai dengan amanah Pasal $28 \mathrm{H}$ ayat (1), ayat (2), ayat (3) serta Pasal 34 ayat (1) dan ayat (2) UUD 1945 sehingga selanjutnya dibentuk aturan yang memenuhi hak konstitusional bagi 
kepentingan menyeluruh seluruh Warga

Negara Indonesia.

\section{Daftar Pustaka}

Buku

Fatwa, Mappetahang, Andi, 2009, Potret konstitusi pasca amandemen UUD 1945, Penerbit buku Kompas, Jakarta.

Putri, Eka, Asih, 2014, Paham SJSN Sistem Jaminan Sosial Nasional, Friederich-Ebert-Stiftung, Jakarta.

Atmakusumah, 1997, Tajuk - tajuk Mochtar Lubis di Harian Indonesia Raya, Yayasan Obor Indonesia, Jakarta.

Bahar, Saafroedi, 2002, Konteks Kenegaraan Hak Asasi Manusia, Pustaka Sinar Harapan, Jakarta.

Hartono, Dimyati, M, 2009, Problematik dan solusi amandemen Undang Undang Dasar 1945, PT Gramedia Pustaka Utama, Jakarta.

Masduki, 2007, Regulasi penyiaran dari otoriter ke liberal, LKIS Yogyakarta, Yogyakarta.

Budiardjo, Miriam, 2003, Dasar - dasar ilmu politik, Gramedia Pustaka Utama, Jakarta.

Marzuki, Mahmud, Peter, 2005. Penelitian hukum, Prenada media group, Jakarta.

Arrasjid, Chainur, 2001, Dasar - dasar Ilmu Hukum, Sinar Grafika, Jakarta.

Notoatmodjo, Soekidjo, 2010, Ilmu perilaku kesehatan, PT. Rineka Cipta, Jakarta.
Kurnia, Slamet, Titon, 2007, Hak atas derajat kesehatan optimal sebagai HAM di Indonesia, PT. Alumni, Bandung.

Jurnal

Shihab, Nizar, Ahmad, 2012, Hadirnya negara di tengah rakyatnya pasca lahirnya undang - undang nomor 24 tahun 2011 tentang Badan Penyelenggara Jaminan Sosial, Jurnal Legislasi Indonesia Vol. 9 No. 2, ISSN 0216-1338, Jakarta.

Mundiharno, 2012, Peta jalan menuju universal coverage jaminan kesehatan, Jurnal Legislasi Indonesia Vol. 9 No. 2, ISSN 02161338, Jakarta.

Qomarudin, 2012, Badan hukum publik Badan Penyelenggara Jaminan Sosial dan transformasinya menurut undang - undang nomor 24 tahun 2011 tentang Badan Penyelenggara Jaminan Sosial, Jurnal Legislasi Indonesia Vol. 9 No. 2, ISSN 0216-1338, Jakarta.

Pakpahan, Hendra, Rudy \& Sihombing, M.A.N, 2012, Eka Tanggung jawab negara dalam pelaksanaan jaminan sosial, Jurnal Legislasi Indonesia Vol. 9 No. 2, ISSN 02161338, Jakarta.

Zaelani, 2012, Komitmen Pemerintah dalam penyelenggaraan jaminan sosial nasional, Jurnal Legislasi Indonesia Vol. 9 No. 2, ISSN 02161338, Jakarta.

Internet

https://id.wikipedia.org/wiki/Kesehatan diakses tanggal 13 April 2016. 
http://www.jkn.kemkes.go.id/detailfaq.php ?id=1 diakses tanggal 13 April 2016.

http://regional.kompas.com/read/2014/02/ 21/Mau.Cuci.Darah.Jadi.Rumit.den gan.BPJS diakses tanggal 15 Maret 2016.

http://wandykumis.wordpress.com/2010/0 2/24/penalaran-induktifdeduktifanalogi-silogisme-kategorial/, diakses tanggal 26 Mei 201.

http://iki.or.id/publikasi/apa-saja-hakkonstitusional-kita-sebagai-wni diakses tanggal 30 November 2014.

http://www.jamkesindonesia.com/topik/det ail/asas--tujuan-dan prinsip\#.VIBzFGcmHNw diakses tanggal 30 November 2016. 